\title{
Banking Sector and Monetary Policy Transmission: Bank Capital, Credit and Risk-Taking Channels
}

\author{
Philippe Gilles, Marie-Sophie Gauvin, Nicolas Huchet \\ Université de Toulon, LEAD, Toulon, France \\ Email: ph.gilles@univ-tln.fr
}

Received November 16, 2012; revised December 17, 2012; accepted January 8, 2013

\begin{abstract}
In the literature, the question of central banks' responsibility for triggering crises is raised when sustainable low interest rates lead to excessive banks' risk exposures. However, such portfolio choices mainly depend on the various returns of assets and on the official interest rate, taking into account that the bank lending channel is affected by the bank capital channel. On the basis of a simple theoretical model including a solvency ratio, we show that during recessions a credit rationing is observed together with a flight to quality; during expansions monetary policy can induce both a fall in credit activity and an increase in financial instability. Then, regulatory capital arbitrages appear and still weaken productive loans. Conclusions can be drawn in terms of prudential policy, as the central bank may be powerless face to banking strategies if the regulatory framework is procyclical.
\end{abstract}

Keywords: Banking Sector; Credit Channels; Monetary Policy; Prudential Policy

\section{Introduction}

Some arguments challenge the goals and tools of central banks, which are regarded as being responsible for the outbreak of the 2007-2008 crisis, especially via the risktaking channel. Financial innovations and off-balance sheet activities have led to a new business model and favor regulatory capital arbitrage. Despite the possible role of central banks, such a framework requires an evolution in prudential and regulatory systems.

The aim of this paper is to highlight the evolution of performance and soundness indicators according to the conduct of monetary policy but also market incentives. The underlying idea is to compare banks that use securitization and off-balance sheet activities and banks that prefer the traditional originate-and-hold business model. We are interested in this topic during growth and slowdowns, because of the impact of interest rates, whose level depends on both the price and the growth targets set by central banks. We show how banks' portfolio choices can be oriented towards risky or safety assets, through a theoretical model which presents the aggregate balance sheet of a banking sector. During the ascending phase, banks prefer speculative assets rather than productive funding, while, after the reversal, they rush towards safety assets and also neglect productive credits. In addition, securitization entails new risks and crowds out the traditional credit activity. Arbitrages are explained by net returns of investments (depending on solvency ratios) and by risk perception.

Works presented in the survey (II) have come to the conclusion that price stability is not enough to give financial stability. Besides, recent researches focused on the risk-taking channel and the bank capital channel show that monetary policy can succeed as regards the price target and at the same time promote financial instability. These arguments highlight the questions relative to the prudential regulation and the aims of central banks. Our model (III) tends to show that, one the one hand, productive credit is all the more useless for banks than they don't hold claims but distribute them, on the other hand, it is necessary to assess the impact of bank capital regulation on global risks. Actually solvency ratios give incentives to risky activities, hence financial instability for which central bank is not responsible.

\section{Monetary Policy Transmission and Bank's Behavior: A Survey}

The official interest rates and their expected trajectory determine nominal interest rates and aggregate demand. The credit channel highlights the role of banks and their reaction concerning monetary policy decisions. The financial accelerator stresses the procyclicality of the financial sector [1,2], the amplification effects [3] and the aims of central banks. A major problem concerns the stabilization of the output, implying a current debate about macroprudential regulation and its linkages with 
monetary policy. In accordance with the Jackson Hole Consensus, the price stability and the financial stability are complementary and a flexible inflation targeting should be implemented, with the interest rate as a principal tool and the communication as an other one $[4]^{1}$.

Current models introduce the banking sector in order to identify the main transmission channels of monetary decisions and booms and busts cycles [8-10]. Based on works focused on financial stability goal for central banks [11,12], it is said that there is no consensus about asset prices. The price stability is conducive to financial instability, since it is hard to conciliate an interest rate policy for prices stability and real activity on the one hand, and a banking policy for financial stability (mostly dependent on wealth effects) on the other hand. These arguments sometimes lead to advocate more recurrent rises of interest rates [13,14]. Fahr et al. [15] suggest an inflation target based on a middle term to limit financial instability. Besides, Hobijn and Ravenna [16] introduce securitization and underline the importance of the output at the expense of the inflation.

The main outcome of this literature is the relationship between credit activity and financial instability. The bank lending channel only exists if it is costly to issue debts, relative to required reserves: after a monetary policy tightening, to face the reserves decrease banks prefer to reduce credit activity (or to liquidate assets) to the detriment of new debts with a higher interest rate [17]. Then, the bank capital channel draws this principal conclusion: facing the cost of issuing debts, monetary policy tightening is all the more costly that the level of equities is low. Literature on the bank capital channel focuses on the effects of equity ratios on the credit supply $[18,19]$ : if a crisis occurs, distress sales and (growing) risk aversion lead to amplification effects which in turn imply raising equity to comply with capital requirements, and worsen the credit rationing. Moreover, accounting rules (fair value) strengthen the contraction, through a procyclical effect linked to collateral value [20]. Korinek [21] shows that it is impossible to limit the amplification effects if agents are risk-averse (versus risk neutral, [22]). Here, the new business model (from originate to hold to originate to distribute) leads to an increase in leverage and in

\footnotetext{
${ }^{1}$ Asset prices can be a good prevision tool and so an element of the monetary policy rule, if they contain information about expectations and future inflation $[5,6]$. Nevertheless, included in a rule, asset prices become endogenous and so counterproductive ([7], cf. Goodhart's law).

${ }^{2}$ The microeconomic liquidity [29] depends on the market capacity to absorb great volumes with no impact on prices, and on the market resilience, that is to say the rapidity with which prices get back to their initial level after a random shock. According to the macroeconomic liquidity, an asset is liquid if it can be used as a reserve if needed, so it can't lose value. In 2008, a mortgage does not meet the standards of this second definition.
}

regulatory capital arbitrages: this strategy raises the return on equity (ROE), even if non-interest incomes are more volatile than interest incomes. Moreover, this business model entails a weakening of the bank lending channel and a strengthening of the risk-taking channel $[23,24]$, via an excessive optimism concerning the other banks' default risk and an overestimation of expected returns $[25,26]$. So monetary policies can be responsible for crises, because whenever rates remain durably low, they lead agents to take more risks. The risk-taking channel illustrates not only the reduction of the risk aversion, but also the increase in the impact of the monetary policy on financial stability [27].

Actually, the credit channel, the risk-taking channel and the bank capital channel are tightly linked. Equities requirements entail an opportunity cost for banks, which favor at the expense of the productive credit risk-taking and securitization [28]. After the reversal, banks reconstitute their capital ratios and so strengthen the credit crunch. In other words, as regards as assets, preferences depend on the phases of the economic cycle. Speculative assets and/or microeconomic liquidity are preferred during the upward phase and the reversal triggers a preference for macroeconomic liquidity ${ }^{2}$. In fine, choices are always made at the expense of productive loans. These results legitimate recommendations for monetary and macroprudential policies, as a countercyclical action of the central bank to avoid bubbles [30,31]. For instance, a countercyclical capital ratio can limit assets and output volatility [32] while price targeting could be realized with fewer variations of interest rates [33]. However, such macroprudential recommendations cannot work if the microprudential regulation entails rise in risk-taking. As showed by Blum [34], a capital ratio can reduce the supply of productive credit and at the same time promote speculative assets. Our model highlights possible harmful aftermath of microprudential regulation that should be taken into account during debates on monetary policy. Actually, the new proposal of the Basel Committee on Banking Supervision is better than previous, for example thanks to the introduction of a leverage ratio, but it still maintain procyclical effects and risk measurement by bankers themselves. We show that monetary and microprudential policies can favor risky assets at the expense of productive loans, and underline the weakening of the credit channel and the rise in financial instability. Securitization and off balance sheet activities reduce the costs of equities but increase risks.

\section{Analytical Framework}

The interactions among banks' portfolio choices depend on monetary policy and can be harmful for credit activity, whatever the phase of the cycle (I and II). In $t_{0}$ the banking sector's aggregate balance sheet is composed of $I_{i}$ assets 
depending on portfolio choices, in order to maximize profit. Liabilities are divided into equities $K_{t_{0}}$, which correspond to a share $\alpha_{i}$ of assets $\left(\alpha_{i}<\left[1-\alpha_{i}\right]\right)$, and the debts $D_{t_{0}}$ (cf. Table 1).

In $t_{1}$ the Central Bank (whose function is to maximize the welfare: maximization of GDP and minimization of inflation), can change the official interest rate (the aggregate balance sheet is known), and banks make their portfolio choices. A decrease (increase) in the official interest rate is associated to perspectives of rise (contraction) in growth and credit and entails an expansion (reduction) of the aggregate balance sheet of the banking sector, with a new structure, with probabilities $p$ and $(1-p)$. In $t_{2}$ the volume of assets of the banking sector depends on previous choices in $t_{1}$ from the initial situation $t_{0}$. The growth of assets relies on the net supply of funding $\rho_{i}$ (or net demand of assets). It can be equal to the (exogenous) demand $\left(\rho_{i}=1\right)$, more $\left(\rho_{i}>1\right)$ or less $\left(0<\rho_{i}<1\right)$. It includes a yield $R_{i}$ for assets $I_{i}$. In case of excess demand (supply), the volume of assets (recorded with fair value rules) is raised (decreased) because of a wealth effect which is included through a coefficient $\mu_{i}$ :

$$
I_{i t_{2}}=I_{i t_{0}}\left[1+R_{i}+\rho_{i} \mu_{i}\right]
$$

$\mu_{i}>0$, with, for $I_{i}$ assets:

$$
\mu_{i}\left\{\begin{array}{l}
<1, \text { si } \rho_{i}<1 \\
>1, \text { si } \rho_{i}>1 \\
=1, \text { si } \rho_{i}=1
\end{array}\right.
$$

$0<R_{i}<1$. It is a net return, that is to say the difference between the yield of the claim $r_{i}$ and the bank's funding cost, which at least corresponds to the interest rate of the central bank $r_{B C}$ :

$$
R_{i}=r_{i}-r_{B C}
$$

A high (low) variance $\sigma_{i}^{2}$ implies that $I_{i}$ asset is riskier (less risky). About liabilities in $t_{2}$ :

$$
\begin{gathered}
K_{t_{2}}=\alpha_{i} I_{i t_{0}}\left[1+\rho_{i} \mu_{i}\right] \\
D_{t_{0}}=\left(1-\alpha_{i}\right) I_{i t_{0}}\left[1+\rho_{i} \mu_{i}\right]
\end{gathered}
$$

There is no distribution of benefits, hence new quasi

Table 1. Aggregate balance sheet of the banking sector in $t_{0}$.

\begin{tabular}{cl}
\hline Assets & \multicolumn{1}{c}{ Liabilities } \\
\hline$I_{i_{0}}$ & $K_{t_{0}}=\alpha_{i} I_{i}$ \\
& $D_{t_{0}}=\left(1-\alpha_{i}\right) I_{i}$ \\
\hline
\end{tabular}

${ }^{3}$ Note that the model uses a given probability of risk aversion. Making endogenous the coefficient $a$ would constitute an improvement, implying a dynamic study over the cycle. equities $(R A N)$ :

$$
R A N=I_{i t_{0}} R_{i}
$$

\subsection{Behavioral Equations}

The central bank wishes to minimize losses due to the difference between real activity and inflation and their expected levels:

$$
\min \left[L=\frac{1}{2}\left(\pi-\pi^{*}\right)^{2}+\theta\left(\mathrm{GDP}-\mathrm{GDP}^{*}\right)^{2}\right]
$$

With $L$ the losses of the central bank, $\pi$ the effective inflation rate, $\pi^{*}$ the inflation target, GDP the national income, GDP* the potential national income (the difference equals to the output gap) and $\theta$ the relative weight of the aim on GDP compared to the inflation's one. The tool that satisfies this function is the interest rate complying with the Taylor rule:

$$
r_{B C}=\pi+r^{r}+b\left(\pi-\pi^{*}\right)+c\left(\mathrm{GDP}-\mathrm{GDP}^{*}\right)
$$

With $r^{r}$ the real interest rate and $b>0, c>0$. When output growth and inflation are too high, the Central Bank increases the interest rate $r_{B C}$ and conversely. So the latter is crucial to assess the banking sector reaction to monetary policy.

Banks maximize profit:

$$
\max \left[U\left(R_{P}, \sigma_{P}\right)=R_{P}-a \sigma_{P}^{2}\right]
$$

With $P$ the assets portfolio, $R_{P}$ its net yield:

$$
\left(R_{P}=\sum_{i=1}^{N} R_{i}\right),
$$

and a the risk aversion coefficient. The latter depends on the cycle: $p\left(a=a^{\mathrm{I}}\right)=p$ and $p\left(a=a^{\mathrm{II}}\right)=1-p$, with $a^{\mathrm{I}}<a^{\mathrm{II}}$ since risk aversion is higher during recessions ${ }^{3}$. Over several periods, banks are supposed to be risk neutral [35]. $a \sigma_{P}^{2}$ measures the portfolio risk according to risk aversion.

With [3], we understand how portfolio choices are made according to expectations, which in turn depend on the official interest rate. If banks observe or expect to a rise in interest rates, then they also expect a higher cost of capital. On the opposite, when low interest rates are set, they expect growth and a lower cost of capital. The (I) configuration with low interest rate is conducive to a growth of credits $\left(\rho_{i}>0\right)$, while the (II) configuration favors a flight to quality, preventing banks from extending credits and private assets $\left(\rho_{i}<0\right)$ : $\rho_{i}=f^{-}\left(r_{B C}\right)$.

\subsection{Assets and Accounting Equilibrium}

Assuming three types of assets $(i=1,2,3)$, we present the balance sheet of the banking sector ( $c f$. Table 2). 
Table 2. Balance sheet of the banking sector.

\begin{tabular}{cc}
\hline Assets & Liabilities \\
\hline$I_{1}$ & $K$ \\
$I_{2}$ & $R A N$ \\
$I_{3}$ & $D$ \\
\hline
\end{tabular}

$I_{1}$ is a safety asset (e.g. Treasury Bond), $I_{2}$ is backed on a productive project and $I_{3}$ is a speculative asset without linkage with real activity. To focus on banks' behavior, we don't specify the maturity of assets. The speculative assets $I_{3}$ include issuances by other financial intermediaries in order to increase leverage: Asset Backed Securities (ABS) and Asset Backed Commercial Paper (ABCP). As $I_{1}$ is a safety asset, it does not give any yield $\left(r_{1}=r_{B C}\right)$ and does not require any equity. During the expansion phase, $I_{3}$ asset gives a higher net yield than $I_{2}$ but is also riskier:

$$
R_{1}=0<R_{2}<R_{3}<1
$$

and:

$$
\sigma_{1}^{2}=0<\sigma_{2}^{2}<\sigma_{3}^{2}<1
$$

To simplify, the yield/risk ratio for $I_{2}$ and $I_{3}$ is equal:

$$
\left(\frac{R_{2}}{\sigma_{2}^{2}}=\frac{R_{3}}{\sigma_{3}^{2}}\right)
$$

Nevertheless, the risk of $I_{3}$ is higher, so it requires more equities as regards prudential solvency ratios: $\alpha_{1}=0<\alpha_{2}<\alpha_{3}$.

The bank portfolio choices depend on the yield of assets but also on the cost of equities: with the hypothesis of an average neutrality of risk aversion, none of the assets $I_{2}$ and $I_{3}$ is preferred since:

$$
\frac{R_{2}}{\alpha_{2}}=\frac{R_{3}}{\alpha_{3}}
$$

and $E\left(R_{2}\right)=E\left(R_{3}\right)$. To diversify risks, banks select a similar growth of these assets: $\rho_{2}=\rho_{3}=\rho$. But $I_{1}$ and $I_{2}$ are not recorded with fair value rules $\left(\mu_{1}=\mu_{2}=1\right)$, unlike $I_{3}$ : when its demand (by banks) is higher than supply, the "fair value" is sharply increasing $\left(\mu_{3}>1\right)$, and conversely $\left(\mu_{3}<1\right)$. To simplify: $\mu_{3}=\mu$.

Last, $I_{1}$ represents an insurance against liquidity risk. It is used as a collateral in case of refinancing operations by the central bank, hence its inclusion for a proportion $\beta$ of debts:

\footnotetext{
${ }^{4}$ We have $(11)+(12)+(13)=\left(4^{\prime}\right)+\left(5^{\prime}\right)+\left(6^{\prime}\right)$. The central bank cannot observe the number of the claims but their amount. The equilibrium of the balance sheet is explained as following: the Treasury Bonds $I_{1}$, being a share of debts are both in the asset and liability sides. The credits $I_{2}$ appear in the balance sheet of the counterparts as deposits. The speculative assets $I_{3}$ are also in the liability side since they are issued by other institutions.
}

$$
I_{1} \geq \beta D
$$

The aggregate balance sheet of the banking sector is determined as follows ${ }^{4}$ ( $c f$. Table 3).

Now we can observe the evolution of assets and liabilities, but also performance and resilience indicators, from $t_{0}$ to $t_{2}$, i.e. during high or low growth.

\section{Results: Banks Choices and Transmission of Monetary Policy}

The analytical framework highlights incentives produced by the objectives of financial profitability to the detriment of resilience indicators. (I) characterizes a phase of strong growth and (II) a recession: $R_{i}^{\mathrm{I}}>R_{i}^{\mathrm{II}}, \forall i=2,3$ and $\rho^{\mathrm{I}}>1$ et $\rho^{\mathrm{II}}<1$.

Consequently: $(\mu \rho)^{\mathrm{I}}>1$ and $0<(\mu \rho)^{\mathrm{II}}<1$.

\subsection{Banks Incentives and Stylized Facts}

The financial profitability (ROE) can be expressed by the following Results/Equities ratio. From [4'] et [6']:

$$
\frac{R A N_{t_{2}}}{K_{t_{2}}}=\frac{R_{i}\left(I_{2, t_{0}}+I_{3, t_{0}}\right)}{\alpha_{i}\left[\left(I_{2, t_{0}}+I_{3, t_{0}}\right)+\rho\left(I_{2, t_{0}}+\mu I_{3, t_{0}}\right)\right]}
$$

We find:

$$
\left(\frac{R A N_{t_{2}}}{K_{t_{2}}}\right)^{\mathrm{I}}>\left(\frac{R A N_{t_{2}}}{K_{t_{2}}}\right)^{\mathrm{II}}
$$

Under the condition:

$$
R_{i}^{\mathrm{I}}>\alpha_{i}[1+\rho(1+\mu \rho)]^{\mathrm{I}}>\alpha_{i}[1+\rho(1+\mu \rho)]^{\mathrm{II}}>R_{i}^{\mathrm{II}} .
$$

The condition is satisfied as soon as the fixed solvency ratio is lower (higher) than expected yields during ascending (downturn) phase. The observed financial profitability is higher during growth, together with a rise in individual and contagious risks. The first can be approached by asimple solvency ratio (capital/assets). From (4'), (11), (12) and (13):

Table 3. The aggregated balance sheet of the banking sector.

\begin{tabular}{c}
\hline Assets \\
\hline$I_{1 t_{2}}=I_{1 t_{0}}\left(1+\rho_{1}\right)$ \\
$I_{2 t_{2}}=I_{2 t_{0}}\left(1+R_{2}+\rho\right)$ \\
$I_{3 t_{2}}=I_{3 t_{0}}\left(1+R_{3}+\rho \mu\right)$ \\
Liabilities \\
$K_{t_{2}}=\alpha_{i}\left[\left(I_{2, t_{0}}+I_{3, t_{0}}\right)+\rho\left(I_{2, t_{0}}+\mu I_{3, t_{0}}\right)\right]$ \\
$R A N_{t_{2}}=R_{i}\left(I_{2, t_{0}}+I_{3, t_{0}}\right)$ \\
$D_{t_{2}}=\left(1-\alpha_{i}\right)\left[\left(I_{2, t_{0}}+I_{3, t_{0}}\right)+\rho\left(I_{2, t_{0}}+\mu I_{3, t_{0}}\right)\right]+I_{1}$
\end{tabular}




$$
\begin{aligned}
& \frac{K_{t_{2}}}{I_{1 t_{2}}+I_{2 t_{2}}+I_{3 t_{2}}} \\
= & \frac{\alpha_{i}\left[\left(I_{2, t_{0}}+I_{3, t_{0}}\right)+\rho\left(I_{2, t_{0}}+\mu I_{3, t_{0}}\right)\right]}{I_{1, t_{0}}\left(1+\rho_{1}\right)+I_{2, t_{0}}\left(1+R_{2}+\rho\right)+I_{3, t_{0}}\left(1+R_{3}+\rho \mu\right)}
\end{aligned}
$$
(II):

Giving the variables' specification during states (I) and

$$
\left(\frac{K_{t_{2}}}{I_{1 t_{2}}+I_{2 t_{2}}+I_{3 t_{2}}}\right)^{\mathrm{I}}<\left(\frac{K_{t_{2}}}{I_{1 t_{2}}+I_{2 t_{2}}+I_{3 t_{2}}}\right)^{\mathrm{II}} .
$$

Here, the increase in individual risk in phase (I) is clearly underscored, with $\alpha$ unchanged. Now, let's observe contagious risks thanks to the leverage (debts/ capital). From (4') et (5'):

$$
\begin{aligned}
& \frac{D_{t_{2}}}{K_{t_{2}}} \\
= & \frac{\left(1-\alpha_{i}\right)\left[\left(I_{2, t_{0}}+I_{3, t_{0}}\right)+\rho\left(I_{2, t_{0}}+\mu I_{3, t_{0}}\right)\right]+I_{1, t_{0}}\left(1+\rho_{1}\right)}{\alpha_{i}\left[\left(I_{2, t_{0}}+I_{3, t_{0}}\right)+\rho\left(I_{2, t_{0}}+\mu I_{3, t_{0}}\right)\right]} .
\end{aligned}
$$

Since $\left(1-\alpha_{i}\right)>\alpha_{i}$, we have:

$$
\frac{D}{K}>1
$$

and: $\quad\left(\frac{D_{t_{2}}}{K_{t_{2}}}\right)^{\mathrm{I}}>\left(\frac{D_{t_{2}}}{K_{t_{2}}}\right)^{\mathrm{II}}$.

So, (I) make happen a better performance of the banking sector, a decrease in capital adequacy and a higher contagious risk. These indicators reverse in (II). Looking at data on developed countries, we obtain an illustration (Figures 1 to 3):

Financial profitability and leverage are increasing before the crisis for the selected countries. Besides, we in-

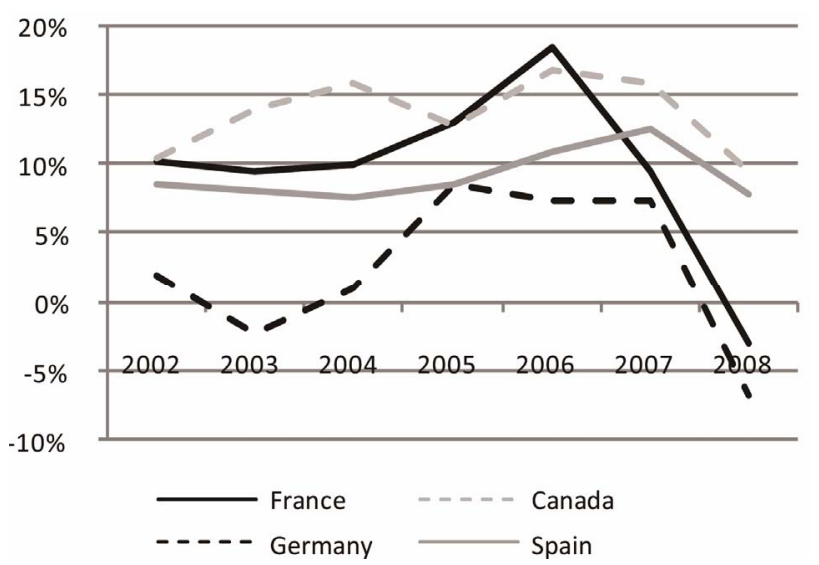

Figure 1. Financial profitability evolution, ROE (caption: OECD, authors' calculations). troduce the United-States, whose capital ratio is artificially increased by regulatory capital arbitrage ( $c f$. post). Here, equities are rather low during growth, and rise after the reversal. Non-performing loans sharply increase in this context ( $c f$. Figure 4).

Last, the central bank is sensitive to macroeconomic liquidity, defined by the liquidity/assets ratio (independent from the volume of deposits): From (11), (12) and (13):

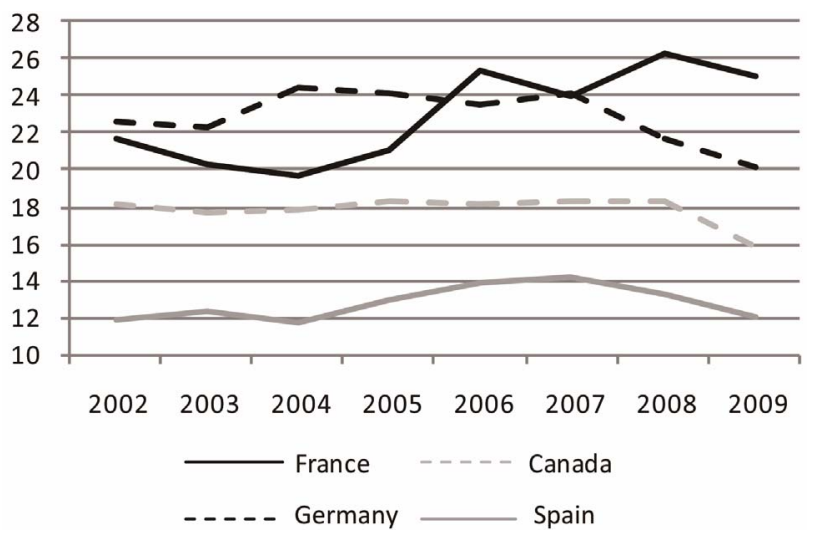

Figure 2. Leverage evolution in \% (caption: OECD, authors' calculations).

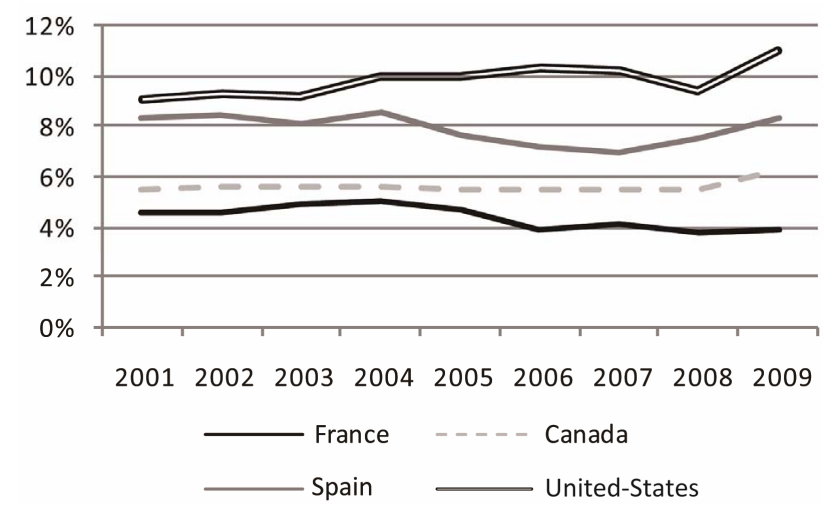

Figure 3. Capital ratio evolution (caption: OECD, authors' calculations).

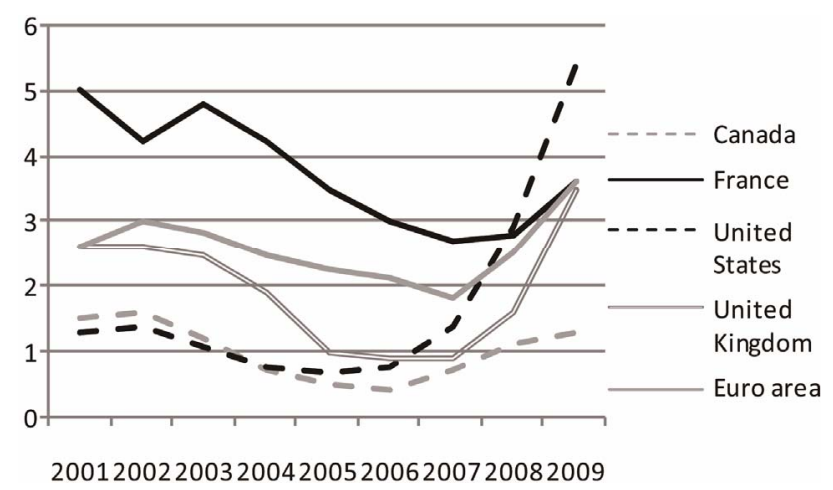

Figure 4. Non-performingloans to the loans portfolio in \% (caption: World Bank, authors' calculations). 


$$
\begin{aligned}
& \frac{I_{1 t_{2}}}{I_{1 t_{2}}+I_{2 t_{2}}+I_{3 t_{2}}} \\
&= \frac{I_{1, t_{0}}\left(1+\rho_{1}\right)}{I_{1, t_{0}}\left(1+\rho_{1}\right)+I_{2, t_{0}}\left(1+R_{2}+\rho\right)+I_{3, t_{0}}\left(1+R_{3}+\rho \mu\right)} \\
& \text { get: } \quad\left(\frac{I_{1 t_{2}}}{I_{1 t_{2}}+I_{2 t_{2}}+I_{3 t_{2}}}\right)^{\mathrm{I}}<\left(\frac{I_{1 t_{2}}}{I_{1 t_{2}}+I_{2 t_{2}}+I_{3 t_{2}}}\right)^{\mathrm{II}}
\end{aligned}
$$

During (I), there is a debt increase and a decrease in liquidity ratio. It looks like Minsky's idea [36], that is to say, the linkage between balance sheets evolution and the use of financial innovations leads to financial embrittlement. This result is explained by the difference between micro and macroeconomic liquidity. The asset $I_{1}$ is liquid, while $I_{3}$ is only liquid if growth is strong (microeconomic liquidity). Indeed, $I_{3}$ rapidly drains in the down phase because supply grows faster than demand and accounting rules are procyclical.

\subsection{Diversification: Decrease in Productive Assets and Increase in Speculative Assets}

Risk aversion changes together with growth and then preconditions portfolio choices. Banks' preferences move towards risky (safety) assets when risk aversion is weak (strong).

$$
\begin{gathered}
\frac{I_{3 t_{2}}}{I_{2 t_{2}}}=\frac{I_{3, t_{0}}\left(1+R_{3}+\rho \mu\right)}{I_{2, t_{0}}\left(1+R_{2}+\rho\right)} \\
\left(\frac{I_{3 t_{2}}}{I_{2 t_{2}}}\right)^{I}>\left(\frac{I_{3 t_{2}}}{I_{2 t_{2}}}\right)^{I I}
\end{gathered}
$$

then:

Speculative assets are preferred during (I), while the yield/risk ratio is supposed to be unchanged. As in Adrian and Shin's model [37], these choices are made to the detriment of productive loans: the credit rationing testifies to the limits of the interest rate tool, in a context where financial innovations allow substituting credits by other types of assets. On the opposite:

$$
\frac{I_{1 t_{2}}}{I_{2 t_{2}}}=\frac{I_{1, t_{0}}\left(1+\rho_{1}\right)}{I_{2, t_{0}}\left(1+R_{2}+\rho\right)}
$$

Choices are still unambiguous:

$$
\left(\frac{I_{1 t_{2}}}{I_{2 t_{2}}}\right)^{\mathrm{I}}<\left(\frac{I_{1 t_{2}}}{I_{2 t_{2}}}\right)^{\mathrm{II}}
$$

Safety assets are preferred in (II), which corresponds to a flight to quality in a context of high risk aversion (or/ and uncertainty). Moreover, this preference is due to the losses caused by the fair value rule for $I_{3}$.

Financial markets favor risks' diversification. Conse- quently, even if the interest rate would have no effect on credit, the possibility for banks to choose financial assets supplants the credit channel. Banks are exposed to market risk $\left(\sigma_{3}^{2}>\sigma_{2}^{2}\right)$, which provides higher returns $\left(E\left(R_{3}\right)>E\left(R_{2}\right)\right)$ and profits $(R A N)$ (Risk-taking channel). This situation is observed when the high amount of equities linked to $I_{3}$ (bank capital channel) is offset by a wealth effect under "fair value" rule.

A simple Taylor rule can entail financial instability because of a weakening of the financial accelerator concerning non-financial sector, for which loans require high equities without wealth effects coming from accounting rules. This result doesn't match with the increase in the credit until the subprime crisis, but this paradox can be explained by the growing share of securitized mortgage loans.

\subsection{Securitization and Off-Balance Sheet: Financial Instability and Flight to Quality}

According to the Equation (16), bank leverage increases during the upward phase in order to improve profitability. We observe this trend for European banks, which have a higher leverage in 2007 than American banks: the gap is explained by off-balance sheet activities. These changes regarding to the business model have to be taken into account, as it implies a risk transfer and stresses the role of consolidated balance sheets. Securitized assets are not backed to a productive project, so they are contained in $I_{3}$, whose characteristics change. The cost of protection (i.e. Credit Default Swap [CDS]'s premium $g$ ) decreases the return $R_{3}$. To simplify, we assume that this premium equalizes net returns of $I_{2}$ and $I_{3}$ :

$R_{3}=r_{3}-r_{B C}-g=R_{2}$.

The demand of funding is increased by the introduction of the shadow banking system. In these conditions, we assume that price effects entailed by accounting standards are higher: $\mu^{\prime}>\mu$. During (I), $I_{3}$ are even more preferred than without securitization, since the wealth effect $\mu^{\prime}$ is reinforced but also because there are no required equities (off balance). Consequently, prudential regulation is weaker: $\alpha_{3}^{\prime}=0<\alpha_{2}$. The Table 4 presents the consolidated balance sheet of the banking sector.

The growth of the balance sheet between $t_{0}$ and $t_{2}$ entails a modification of its composition in favor of $I_{3}$. These assets are linked to Special Purpose Vehicules (SPV), which are registered in offshore financial centers, where regulatory (and fiscal) requirements are less binding. Following a positive growth shock in $t_{1}$, this business model ("originate and distribute": OD) gives results in $t_{2}$, that we compare with the "originate and hold" $(\mathrm{OH})$ system.

On the one hand, we show that $R A N_{O D}^{\mathrm{I}}<R A N_{O H}^{\mathrm{I}}$ and $K_{O D}^{\mathrm{I}}<K_{O H}^{\mathrm{I}}$. On the other hand: 
Table 4. Consolidated balance sheet of the banking sector.

\begin{tabular}{c}
\hline Assets \\
\hline$I_{1 t_{2}}=I_{1 t_{0}}\left(1+\rho_{1}\right)$ \\
$I_{2 t_{2}}=I_{2 t_{0}}\left(1+R_{2}+\rho_{2}\right)$ \\
$I_{3 t_{2}}=I_{3 t_{0}}\left(1+R_{2}+\rho_{3} \mu^{\prime}\right)$ \\
Liabilities \\
$K_{t_{2}}=\alpha_{2}\left(I_{2, t_{0}}+\rho_{2} I_{2, t_{0}}\right)$ \\
$R A N_{t_{2}}=R_{2}\left(I_{2, t_{0}}+I_{3, t_{0}}\right)$ \\
$D_{t_{2}}=\left(1-\alpha_{2}\right)\left(I_{2, t_{0}}+\rho_{2} I_{2, t_{0}}\right)+I_{3, t_{0}}+\rho_{3} \mu^{\prime} I_{3, t_{0}}+I_{1}$
\end{tabular}

$$
\left(\frac{R A N}{K}\right)_{O D}^{\mathrm{I}}>\left(\frac{R A N}{K}\right)_{O H}^{\mathrm{I}}
$$

Financial profitability (ROE) increases because of the higher volume of assets entailed by the shadow banking system and the wealth effects linked to $I_{3}$. This result is no longer valid if the returns of $I_{3}$ are lower than those of $\mathrm{I}_{2}{ }^{5}$.

In addition, we have:

$$
\left(\frac{I_{1}}{I_{1}+I_{2}+I_{3}}\right)_{O D}^{\mathrm{I}}<\left(\frac{I_{1}}{I_{1}+I_{2}+I_{3}}\right)_{\mathrm{OH}}^{\mathrm{I}}
$$

The liquidity ratio decreases because liquid assets $I_{1}$ represent a share $\beta$ of debts and because $I_{3}$ are transferred towards SPV: liquidity provided by nonbanks highlights the question of the money creation. The collapse of the liquidity ratio is also explained by the high growth of $I_{3}$, which requires fewer equities.

Then, we show that: $K_{O D}^{\mathrm{I}}<K_{O H}^{\mathrm{I}}$ and:

$$
\left(I_{1}+I_{2}+I_{3}\right)_{O D}^{\mathrm{I}}>\left(I_{1}+I_{2}+I_{3}\right)_{O H}^{\mathrm{I}}
$$

The decrease in equities is more important:

$$
\left(\frac{K}{I_{1}+I_{2}+I_{3}}\right)_{O D}^{\mathrm{I}}<\left(\frac{K}{I_{1}+I_{2}+I_{3}}\right)_{O H}^{\mathrm{I}}
$$

But, as the simple solvency ratio doesn't include off-balance sheet activities, a "buffer" rapidly appears:

\footnotetext{
${ }_{5}^{5}$ Financial profitability is the product of leverage and return on assets. Since (14), the leverage permits to increase the financial profitability. We also show that the ROE is raised if banks securitize their assets, but this result is not available if the return becomes inferior to the productive assets' one, as for Calmès and Théoret [38]. The fall in the ROE is available in a context of great competition or a decrease in distributed benefits.

${ }^{6}$ Indeed, the Fed increases its interest rate from 1 to $5.5 \%$ between 2004 and 2006. In this case, savings from the rest of the world entailed a decrease in long term interest rates [40]. Adrian and Shin [37] show that a monetary policy tightening is able to limit the credit activity according to the rise of interest rates but also according to the term structure of interest rates.
}

$$
\left(\frac{K}{I_{1}+I_{2}}\right)_{O D}^{\mathrm{I}}>\left(\frac{K}{I_{1}+I_{2}+I_{3}}\right)_{O H}^{\mathrm{I}}
$$

Consequently, the securitization permits a reduction of individual risks but also a rise in contagious risk [39].

$$
\text { Indeed: } \quad\left(\frac{D}{K}\right)_{O D}^{\mathrm{I}}>\left(\frac{D}{K}\right)_{\mathrm{OH}}^{\mathrm{I}}
$$

This is explained not only by the rise in indebtedness $\left(D_{O D}^{\mathrm{I}}>D_{O H}^{\mathrm{I}}\right)$ but also by the decrease in equities $\left(K_{O D}^{\mathrm{I}}<K_{O H}^{\mathrm{I}}\right)$. Yet, a bank can decrease its leverage by going out activities from its balance sheet: this ratio is lowered if the funding of $I_{3}$ assets is excluded. Consequently, the latter (artificially) becomes lower than the traditional business model's one. If expectations about assets prices growth become widespread, the bullish movement becomes self-sustaining (bandwagon effect): the rise in interest rate is not enough to reverse the model dynamics in $t_{1}$ and turns to a recession. The weakening of the credit channel implied by market and by off-balance sheet activities is due to less productive projects funding, more financial instability and less interest rate efficiency ${ }^{6}$.

Securitization entails a deeper leverage and a lower macroeconomic liquidity. The reversal is more harmful if leverage is high; microeconomic liquidity disappears following a distrust about ABS; the illiquidity forces banks to sell assets; informational asymmetries are higher and toxic claims progressively come back to the banking sector; the rise in official interest rate deteriorates the solvency of borrowers (graphic 4). This implies an easing in monetary conditions [41], without inflation because refinancing operations will be repaid. Moreover, in a context of recession, liquidity is decreasing because of a drop in credits and in deposits. So, the high rise of the monetary base can happen without great changes in inflation expectations (Figure 5). Besides, the credit risk increases for the central bank due to assets buyouts on secondary markets. The flight to quality is different if public assets are riskier: in the euro zone, banks resort to the deposit facility (Figure 6).

The new business model reinforces previous results about productive credit and financial instability, and the official interest rate is less effective. Unfortunately, the shadow banking system is more attractive if bank solvency regulation is stronger. In case of a crisis accompanied by a deterioration of public securities, the central bank can restore the functioning of money markets but not the quality of intermediation.

\section{Conclusions}

In this model, a growth phase is the outcome of low ef- 


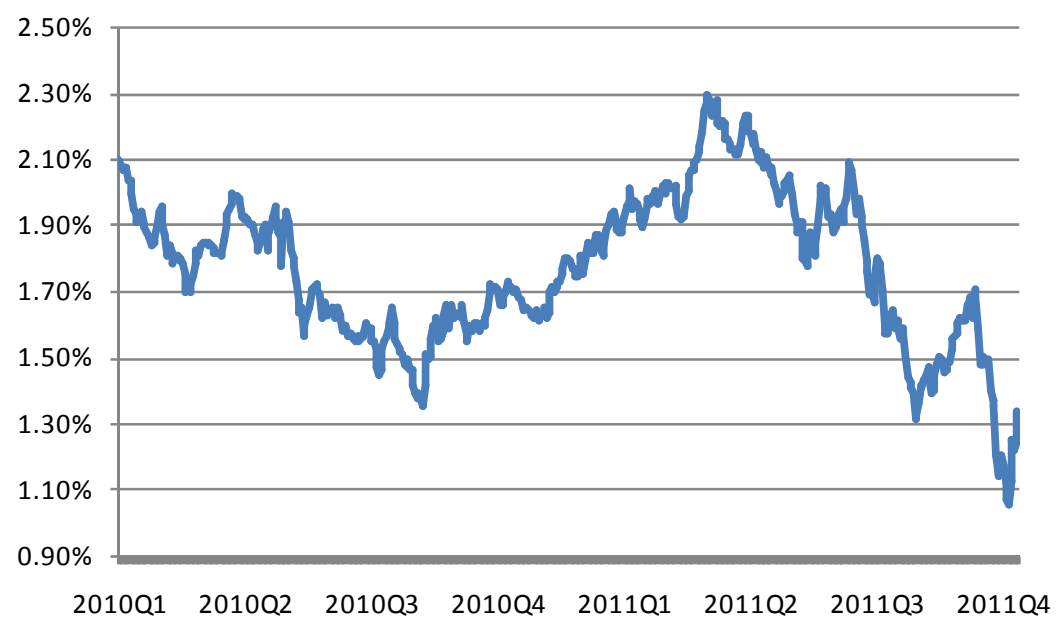

Figure 5. Break-even point in euro-zone (OAT 4.25\% April 2019-OAT€ 1 2.25\% July 2020) (caption: INSEE, authors' calculations).

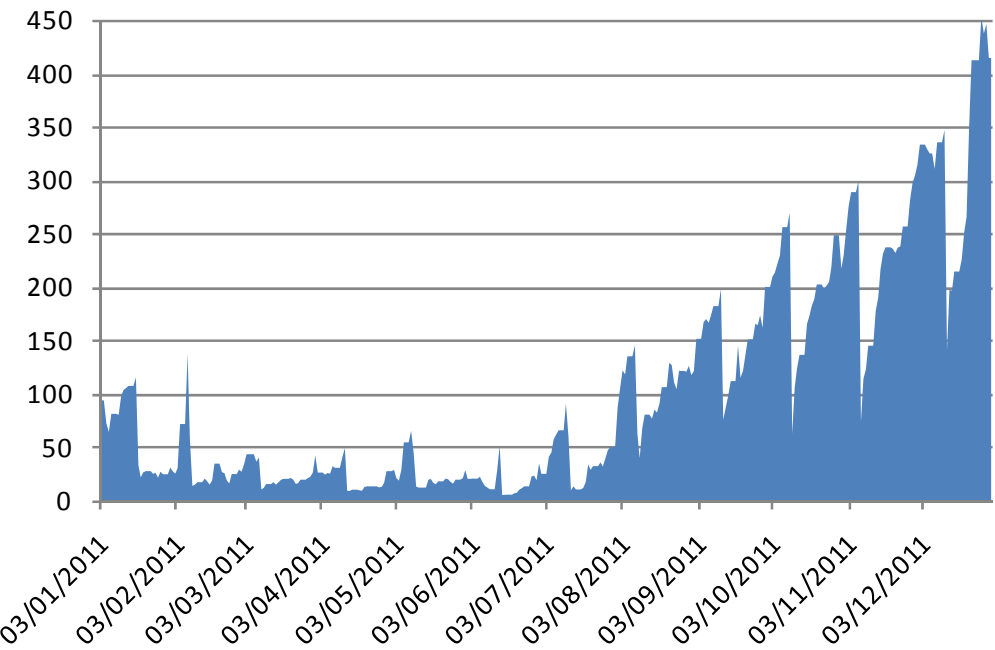

Figure 6. Depositfacilities in euro-zone, end of 2011, Millions of $€$ (caption: ECB, authors'calculations).

fective (and expected) interest rates, considering high net yields. The reversal occurs when banks expect a rise in (nominal) interest rates and/or when official interest rates actually increase. By substituting investors by banks and productive investments by financial assets, this mechanism is described by Minsky: the debt reduction entails a decrease in credits and securities. Instability risks are increased, and the credit channel is less important since productive loans are less rewarding. The usual financial accelerator is weakened but it is still effective through procyclical wealth effects. Given that bank loans are not anymore the only source of money creation, monetary policy could be less focused on the consumption prices indice and more sensitive to financial instability risks.

Securitization and off-balance sheet activities also contribute to the weakening of the credit channel and to the strengthening of the risk-taking channel, with a bigger consolidated balance sheet in the upward phase and relatively more microeconomic liquidity (provided by the shadow banking system). Banks implement strategies to avoid prudential requirements (regulatory capital arbitrage). During the upward phase, due to the investors' search for yields, a possible improvement of monetary policy is linked to macroprudential supervision, for example thanks to a countercyclical solvency ratio. Further, our model highlights the necessary cooperation between central banks and microprudential supervisors, especially if solvency ratios sometimes explain risk exposures. Basel Committee's last recommendations will improve the assessment of credit and market risk, and provide liquidity and leverage ratios. First, these modifications could be harmful in Europe regarding the context of sovereign debt crisis, since it motivates banks to reduce the amount of their assets to comply with prudential requirements. Second, even though it is an improvement, it does not change incentives for banks. In this sense, a banking union 
is desirable, as the choice of the European central bank (not the European Banking Authority) to implement it.

\section{REFERENCES}

[1] B. Bernanke, M. Gertler and S. Gilchrist, "The Financial Accelerator and the Flight to Quality," The Review of Economics and Statistics, Symposium on Developments in Business Cycles Research, Vol. 78, No. 1, 1996, pp. 1-15. doi: $10.2307 / 2109844$

[2] B. Bernanke, M. Gertler and S. Gilchrist, "The Financial Accelerator in a Quantitative Business Cycle Framework," In: M. Woodford and J. Taylor, Eds., Handbook of Macroeconomics, Elsevier, Amsterdam, 1999, pp. 13411393.

[3] N. Kiyotaki and J. Moore, "Credit Cycles," Journal of Political Economy, Vol. 105, No. 2, 1997.

[4] B. Bernanke and M. Gertler, "Should Central Banks Respond to Movements in Asset Prices?" The American Economic Review, Vol. 91, No. 2, 2001, pp. 253-257. doi:10.1257/aer.91.2.253

[5] A. Filardo, "Should Monetary Policy Respond to Asset Price Bubbles? Some Experimental Results," Federal Reserve Bank of Kansas Working Papers, 2001, Paper No. 01-04.

[6] S. G. Cecchetti, H. Genberg and S. Wadhwani, "Asset Prices in a Flexible Inflation Targeting Framework," National Bureau of Economic Research Working Paper, 2002, Paper No. 8970.

[7] G. Levieuge, "Monetary Policy with Financial Information," Review of Political Economy, Vol. 113, No. 2, 2003, pp. 233-254.

[8] M. Brunnermeier and Y. Sannikov, "A Macroeconomic Model with a Financial Sector," Working Paper Research, National Bank of Belgium, 2009.

[9] A. Gerali, S. Neri, L. Sessa and F. Signoretti, "Credit and Banking in a DSGE Model of the Euro Area," Journal of Money Credit and Banking, Vol. 42, No. 6, 2010, pp. 107141. doi:10.1111/j.1538-4616.2010.00331.x

[10] C. Meh and K. Moran, "The Role of Bank Capital in the Propagation of Shocks," Bank of Canada Working Paper, 2010, Paper No. 08-36.

[11] D. Kohn, "Monetary Policy and Asset Prices Revisited," Cato Journal, Vol. 29, No. 1, 2009, pp. 31-44.

[12] C. Walsh, "Using Monetary Policy to Stabilize Economic Activity," Jackson Hole Symposium on Financial Stability and Macroeconomic Policy, 2009.

[13] R. Rajan, "Has Financial Development Made the World Riskier?” NBER Working Paper, 2005, Paper No. 11728.

[14] W. White, "Is Price Stability Enough?" BIS Working Papers, 2006, Paper No. 205.

[15] S. Fahr, R. Motto, M. Rostagno, F. Smet and P. Tristani, "A Monetary Policy Strategy in Good and Bad Times, Lessons from the Recent Past," European Central Bank Working Paper, 2011, Paper No. 1336.

[16] B. Hobijn and F. Ravenna, "Loan Securitization and the
Monetary Transmission Mechanism," Work in Progress. http://ic.ucsc.edu/ fravenna/home/Hobijn_ravenna.pdf

[17] L. Gambacorta and D. Marques-Ibanez, "The Bank Lending Channel. Lessons from the Crisis," BIS Working Papers, 2011, Paper No. 1335.

[18] S. V. den Heuvel, "Does Bank Capital Matter for Monetary Transmission?" Economic Policy Review, 2002, pp. 259-265.

[19] V. Bouvatier and L. Lepetit, "Bank Provision Channel and Credit Market Cyclicality," Economic Review, Vol. 62, 2011, pp. 67-85.

[20] G. D' Ariccia, D. Igan and L. Laeven, "Credit Booms and Lending Standards: Evidence from the Subprime Mortgage Market," IMF Working Paper, 2008, Paper No. 106.

[21] A. Korinek, "Systemic Risk-Taking, Amplification Effects, Externalities, and Regulatory Responses," European Central Bank Working Paper, 2011, Paper No. 1345.

[22] A. Krishnamurthy, "Collateral Constraints and the Amplification Mechanism," Journal of Economic Theory, Vol. 111, No. 2, 2003, pp. 277-292. doi:10.1016/S0022-0531(03)00098-X

[23] M. Ciccarelli, A. Maddaloni and J.-L. Peydro, "Trusting the Bankers: A New Look at the Credit Channel of Monetary Policy," European Central Bank Working Paper, 2010, Paper No. 1228.

[24] Y. Altunbas, L. Gambacorta and D. Marqués-Ibanez, "Securitization and the Bank Lending Channel," European Central Bank Working Paper, 2007, Article ID: 838.

[25] G. Jiménez, J. S. Salas, S. Ongena and J-L. Peydro, "Hazar-Dous Times for Monetary Policy: What Do TwentyThree Million Bank Loans Say about the Effects of Monetary Policy on Credit Risk-Taking?" Banco de Espana Working Papers, 2009, Paper No. 0833.

[26] Y. Altunbas, L. Gambacorta and D. Marqués-Ibanez, "Does Monetary Policy Affect Bank Risk-Taking," European Central Bank Working Paper, 2010, Paper No. 1166.

[27] C. Borio and H. Zhu, "Capital Regulation, Risk-Taking and Monetary Policy: A Missing Link in the Transmission Mechanism?” BIS Working Papers, 2008, Paper No. 268.

[28] C. C. Riportella, R. S. Medina and A. T. Ponce, "What Drives Bank Securitization? The Spanish Experience," Journal of Banking and Finance, Vol. 34, No. 11, 2010, pp. 2639-2651. doi:10.1016/j.jbankfin.2010.05.003

[29] J. Tirole, "Liquidity Shortages: Theoritical Underpinnings," Review of Financial Stability, No. 11, 2008, pp. 57-69.

[30] P. Weill, "Leaning against the Wind," Review of Economic Studies, No. 74, 2007, pp. 1329-1354.

[31] W. White, "Should Monetary Policy 'Lean or Clean'?" Federal Reserve Bank of Dallas, Globalization and Monetary Policy Institute Working Paper, 2009, Paper No. 34.

[32] F. Covas and S. Fujita, "Time-Varying Capital Requirements in a General Equilibrium Model of Liquidity Dependence," Federal Reserve Bank of Philadelphia Working Papers, 2009, Paper No. 09-23.

[33] P. N' Diaye, “Countercyclical Macro Prudential Policies in a Supporting Role to Monetary Policy," IMF Working 
Paper, 2009, Paper No. 09/257.

[34] J. M. Blum, "Why 'Basel II' May Need a Leverage Ratio Restriction," Journal of Banking and Finance, Vol. 32, 2008, pp. 1699-1707.

[35] A. Korinek, "Systemic Risk-Taking, Amplification Effects, Externalities, and Regulatory Responses," European Central Bank Working Paper, 2011, Paper No. 1345.

[36] H. Minsky, "Can 'It' Happen Again? Essays on Instability and Finance," M. E. Sharpe, New York, 1982.

[37] T. Adrian and H S. Shin, "Monetary Cycles, Financial Cycles, and the Business Cycle," Federal Reserve Bank of New-York Staff Reports, 2010, Paper No. 421.

[38] C. Calmès and R. Théoret, "The Impact of Off-BalanceSheet Activities on Banks Returns: An Application if the
ARCH-M to Canadian Data," Journal of Banking and Finance, No. 34, 2010, pp. 1719-1728.

[39] R. Nijskens and W. Wagner, "Credit Risk Transfer Activities and Systemic Risk: How Banks Became Less Risky Individually but Posed Greater Risks to Financial System at the Same Time," Journal of Banking and Finance, Vol. 35, No. 6, 2011, pp. 1391-1398. doi:10.1016/j.jbankfin.2010.10.001

[40] F. Warnock and V. Warnock, "International Capital Flows and US Interest Rates," NBER Working Paper, 2006, Paper No. 12560.

[41] C. Bastidon, P. Gilles and N. Huchet, "Amplification Effects and Unconventional Monetary Policies," Theoretical and Applied Economics, Vol. XIX, No. 2, 2012, pp. 13-30. 